\title{
Analysis Of Need Development Of Literacy Pocket Book Based Cerpen - Gram To Empower Multicultural Characters Of Primary School Students
}

\author{
Khoeri Abdul Muid \\ \{bagusabdi68@yahoo.co.id\} \\ Universitas Muria Kudus, Gondang Manis PO. BOX 53 bae, Kudus, central Java, Indonesia Phone \\ (+62291) 438229, Fax (+62291) 437198
}

\begin{abstract}
This research aims to analyze problems related to Multicultural Character Education Empowerment (PPK) at higher class of Prmary School and to analyze need development of literacy pocket book based on cerpen - gram as multicultural character empowerment for higher class of Primary School. This qualitative decriptive research used observation, interview, and documentation study techniques by using the researcher as the main instrument. The data was analyzed by data reduction, data explanation, data comparisson, and data conclusion steps. The data validity was done through triangulation. The findings of the research showed that PPK in empowering multicultural character based on culture and exemplary method got model limitation. There was almost no variative model at schools, especially in villages, which could be modelized directly by students. Since school society at village was relatively homogeneous and different to urban school society which was heterogeneous, their roles were not fullly relevant to the students' mindsets. In another hand, adult school society members had maturer mindset while the students remained with their child mindsets. In fact, children are not miniatures of adults. There is a need of exemplary model as social - cultural reflection packaged into literacy pocket book based on cerpen - gram (table diagram of short-stroy intrinsict elements). The book consisted of description of child multicultural perspective, the examples of using the book to empower child multiculural character, and forms to fill by students as well as the guidance as internalization strategy of multicultural values.
\end{abstract}

Keywords: Cerpen-Gram, character education, pocket book, multicultural.

\section{Introduction}

Multicultural enriches social - cultural knowledge and is also known as potential cause of conflict [1]. Especially, when it is not well managed so it triggers anti-multicultural characters [2]. Inside of society which has a lot of multicultural, such as Indonesia, should have developed multicultural character. It is a sincere character to recognize and respect differences.

It is very relevant when Indonesia anticipates by empowering character education at school, included multicultural character by sharpening affective aspect as stated in 2013 curriculum. The government also releases several breakthrough as hidden curriculum, such as well - attitude development which is originally taken from school literacy movement (GLS). Then, there are several programs such as character education empowerment (PPK), school literacy movement, and PPK with different nomenclature. All of those efforts are purposed to foster more structured, systematic, and massive character education. However, the fact at several school samples of the preliminary research, the implementation of GLS and PPK still had problems. 
PPK basically aims to promtoe more structured character education, more systematic and masive. However, until its second year, it has not been maximalized promoted, especially in case of empowerment. The preliminary findings at several High Class Primary Schools showed that bulllying phenomenon in their environment was not only within joking context. It had led to anti-multicultural characters which could be developed into intolerance, radicalism, or terorism.

Therefore, there is a need of analysis to (1) causes creating less maximum PPK in empowering multicultural character at High Class Primary School and (2) need analysis to overcome PPK problems in empowering multicultural characters at the class level.

\section{Method}

This descriptive qualitaive research gathered the data from observation, interview, and documentation study. The main instruments were observational guidance, interview guidance, and documentation study procedure. The data was analyzed through data reduction, data explanation, data comparission, and data conclusion. The credibility test of the data was done by observation extension, determination increase in the research, triangulation, peer discussion, negative case analysis, and member check [3].

\section{Result and Discussion}

Multicultural enriches social - cultural knowledge and is also known as potential cause of conflict (Choirul Mahfud, 1997: 8). Especially, when it is not well managed so it triggers anti-multicultural characters (Ki Supriyoko, 2004). Inside of society which has a lot of multicultural, such as Indonesia, should have developed multicultural character. It is a sincere character to recognize and respect differences.

\section{Findings and Discussion}

\subsection{Difficulties in Empowering Multicultural Characters}

At most primary schools, PPK had serious difficulties while empowering the multicultural characters based on culture and exemplary methods. PPK had limitation in multicultural characters. Since there was almost no variative multicultural behavior at schools which could be imitated directly by the students in the village, thus their citizens were homogeneous. However, at urban school society which were heterogeneous, then their acted roles by adult members (teacher and staff) were not fully relevant to the students' mindsets. In another hand, the school society members needed to think maturely while the students should remain having mindset as children. It is important to remember that children are not miniatures of adults.

As formulated by Article 1, clause (1) President Decree Number 82 year 2017 - a rule determined by the president --- jo Article 1 (1) Rules of Indonesian Education Ministry 20 Year 2018 jo Article 1 (1) Rule of Directorate General for Primary and High Education Levels Number: 097/D/HK/2019 that education is under educational unit responsibility to empower character education through affective harmonization, affective management, mindset management, family, and society as parts of National Movement of Mental Revolution (GNRM).

PPK has purpose to develop and prepare learners as golden generation. Indonesia in 2045 with its Pancasila's spirit and proper character education are expected to be able in facing dynamic changes in the futrue (Article 2 (a) President Rule Number 87. Year 2017).

As regulated by Article 6 (1) Rule of Educational Ministry Number 20 Year 2018 and Article 9 (2) Rules of Directorate General of Primary and High School Number 097/D/HK/2019 that PPK promotors which optimize three - center partnership (school, family, and society) should promote it based on school culture, class, and society approaches. 
PPK with school - culture approach could be done by providing exemplary model for school society members (Article 6 (3) (b) rule of education ministry 20 Year 2018). The school society meant by Article 2 (3) Rule of Directorate General of Primary and High Education Levels Number: 097/D/HK/2019) are habitualization, exemplary, and commitment realized by the principals, teachers, educational workers, and school committee.

Exemplary method is a way for individuals in having educational process through action and behaviors which are suitable to model (Modelling) (Syaepul Manan, 2019). Meanwhile, exemplary in education is influential method proven to be successful in preparing and fostering moral, spiritual, and social ethos of the children. According to Ulwan (1992, p.2), educators are the best models within students' persepctives since their politeness and behaviors will be imitated by students unconciously.

\subsection{Need Analysis of Multicultural Character Empowerment}

Problems dealing with appropriate and variative exemplary about multicultural character in the environment of the students could be overcome by utilizing short - story literature work. In these instrinsict short - story elements, there are characters with various characteristics and profiles - developed within child mindset corridors. Literature work is an imitation and reflection of social - cultural realities so that the characters and the plots could be used as exemplary models (example non-example) which indirectly have strength points and does not seem patronizing.

Utilization of short - story as expemplary media and method to empower multiculutral characters of the students could be done by synergizing them into School Literacy Movement (GLS). GLS as explained by Faizah, Dewi Utama [4] in GLS manual book for primary school - it is an effort to create school as learning organization to make literate community for their life through public invovlement. Meanwhile in GLS context, it is ability to access, understand, and use literately through various activities by reading, observing, listening, writing, and/or speaking.

Elma Exacavanti Tamaya et al [5] concluded that reading - writing could be used as a meant to comprehend substantial learning material (learning method) to its determined competences. Secondly, the principles used as bases of reading - writing utilization as learning model surely put students to be willing and able in accessing various learning sources from various perspectives. Third, summarizing, comparing, providing solution, expressing table, and creating visual display are series of activities to create meaningful and comprehensive learning experiences. Fourth, reading - writing could answer $21^{\text {st }}$ century challenges which demanded academicians to be skillful in finding and processing information as well as to use it effectively and sustainably.

Mohammad Kanzunnudin [6] concluded that: (a) literature had important role in education character, (b) literature functioned as catalyst media in learning literature utilized receptively and expressively in character education, (c) it used various theme as media for learners to recognize and understand level quality of characters and their own characteristics, (d) it told and drew various types of characters used as education character media for learners by giving example of character and personality levels to model (Proceeding of National Education Seminar: UMK Kudus). Secondly, literature functioned as learning media used receptively and expressively in character education.

General purposes of GLS are to create better characters of the students through empowering school literacy ecosystem realized in GLS to make them long - life learners. There are three steps of GLS promotion: 1) habitualizing step, to create reading interest by having 15 minute reading time (Rule of Education Ministry Number 23 Year 2015), 2) developing step, to improve literacy ability by responding to enrichment book activity, and 3) 
learning step, to improve literacy skill on all lessons by using enrichment textbooks and reading strategies on all lessons. Here is the map of school literacy development within three schemes of steps.

Table 1: Map of School Literacy Development in 3 Step Scheme [4]

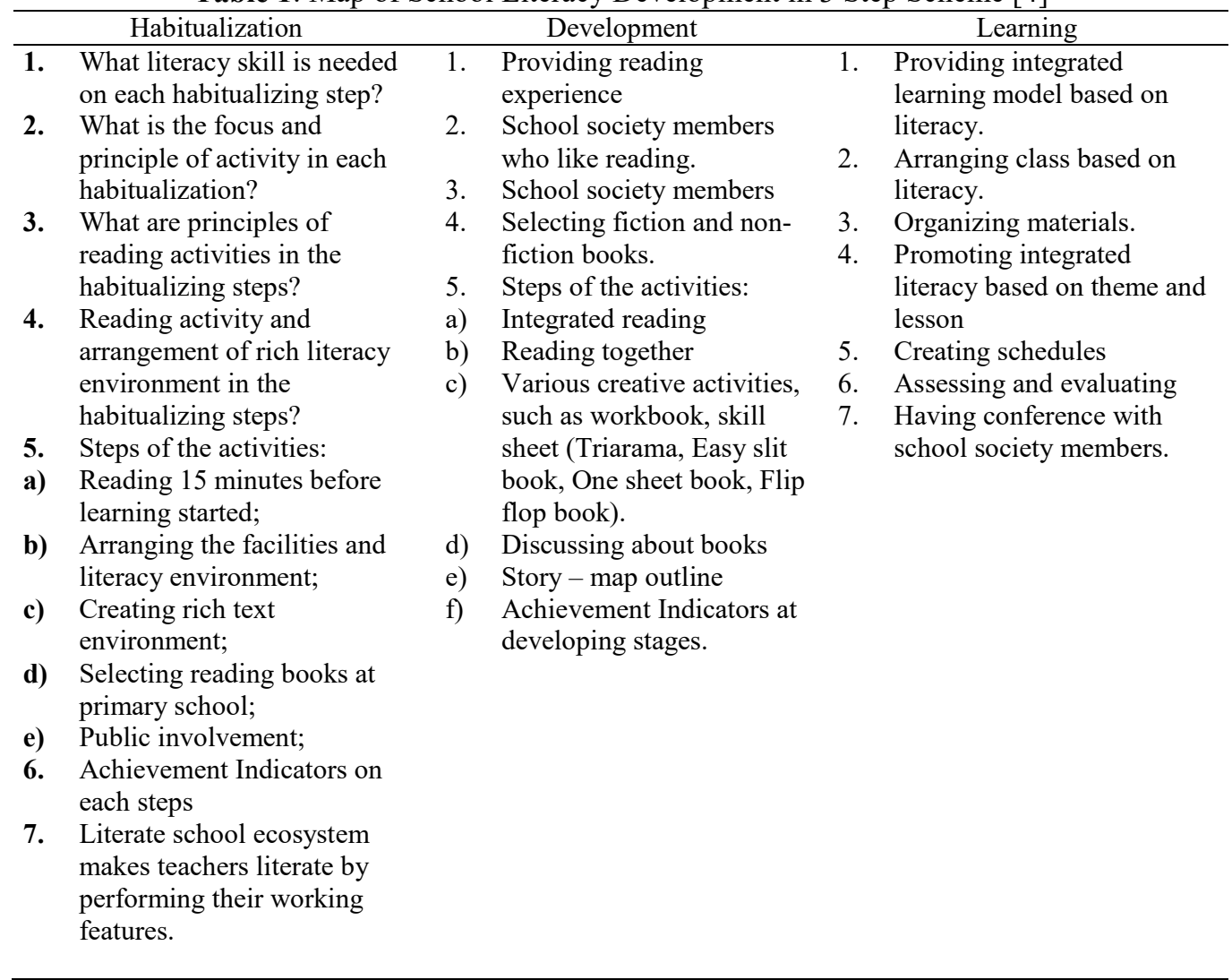

Utilization of short story as exemplary media to empower multicultural characters for high class primary school students during GLS could be started by developing stages since the stages had activity to respond the enrichment books. The literacy ability of the developmental stages at the level as follows.

Table 2: Literacy Skill of High Class Primary School on Developmental Stages [4]

\begin{tabular}{ll}
\hline \multicolumn{1}{c}{ Skills } & \multicolumn{1}{c}{ Explanation } \\
\hline Listening & Listening to create empathy. \\
Reading & Reading fluently. \\
Speaking & Paraphrasing orally and expressing personal opinion toward a story. \\
Writing & - Writing responses to main characters/story plot. \\
& - Writing modification of the story for both beginning, middle, and the ending \\
& parts. \\
\hline
\end{tabular}

It was determined principles of activities in the development stages: reading book should be followed up by drawing, writing, moving, creating, and acting out to respond the text. It 
should be adjusted to the levels and abilities of the students. Its assessment toward reading was non-academic in nature and focused on the students' behaviors. It is suggested for the educators to always motivate the students.

Besides to improve their reading understanding, discussion could help them to analyze the instrinsict elements. To develop better analysis understanding and ability, teacher could make question list as the table shown.

Table 3: Question List

\begin{tabular}{ll}
\hline Elements of the Story & Question List to Develop the Discussion \\
\hline Topics/Themes & Low Class Primary School High Class Primary School \\
on the book's cover? \\
- What do you learn from this story? \\
- What message is delivered by teller/character?
\end{tabular}


Besides the question guided by GLS manual at primary school, it was provided notes after reading such as these rubrics: 1) Me and the Characters, 2) What is said by the character? 3) background knowledge activation, 4) story map, 5) story plot, and 6) new word list.

However, the question list and rubrics still had difficulties in answering and filling them up since the students had difficulties to identify the elements of short story directly. It was needed a medium between short story and the process to answer and fill the rubric. This medium is called cerpen-gram, a table diagram to explain instrinsict elements of short story [7]. The elements explained in cerpen gram reflected multicultures. Besides that, within multicultural context, the rubrics had not specifically directed students to use child short story to empower multicultural characters. Therefore, students and teacher expected to have literacy pocket book development based cerpen - gram (called as Busali Cerpen - Gram) to empower multicultural characters. It was called as pocket book to make it flexible in facilitating the students anytime and anywhere [8] as the short - story characters which could be read anytime and anywhere.

Literacy pocket book based cerpen - gram consisted of multicular description of child perspectives, for example the use of cerpen - gram to empower multicular characters of children, and the fomrs to fill by the students plus the directions as multicultural value internalization strategy. The principles of Busali's work - Cerpen Gram are 1) reading short story, 2) writing instrinsict elements of the short story on cerpen - gram [9], and 3) internalizing values by analyzing and reflecting multicultural values [10], existing in short-story elements, especially the character's profile.

According to Robert, value internalizations were identified as value integration of individuals, or psychologically, it is adjustment of belief, value, behavior, practice, and standard rules on individuals. In internalization process was closely related to student guidance. There are three stages representing internalization process, such as 1) value transformation step, 2) transactional value step, and 3) transinternalization step [11]. Here are the analysis of short-story character analysis by using cerpen - gram.

Table 5: Topics and Titles of the Short Story by Cerpen - Gram 1

\begin{tabular}{|c|c|c|c|c|c|c|}
\hline Topic & & Title & & & heme & \\
\hline Morale & & \multicolumn{3}{|c|}{ We are stronger when we unite. } & nion & \\
\hline \multicolumn{7}{|c|}{ Table 6: Names, Profiles, and Behaviors of Cerpen - Gram 2} \\
\hline \multicolumn{2}{|c|}{ Names } & \multicolumn{3}{|c|}{$\begin{array}{c}\text { Profiles } \\
\end{array}$} & \multicolumn{2}{|c|}{ Behaviors } \\
\hline Male & Female & Low & Moderate & High & Hobby & Characteristics \\
\hline Kevin & - & - & - & $\begin{array}{l}\text { A son of } \\
\text { businessman }\end{array}$ & Badminton & Sympathy \\
\hline Ekrak & - & $\begin{array}{l}\text { A son of a } \\
\text { driver }\end{array}$ & - & - & Badminton & Polite \\
\hline
\end{tabular}

Table 7: Physical Apperance of Cerpen - Gram 3

\begin{tabular}{llllll}
\hline Skin & Head & Hair & Eye & Nose & Eyebrow \\
\hline White & - & Straight & Slanted & Pointed & Thin \\
Brownish & - & Curly & Wide & Flat & Thick \\
\hline & & & & & \\
\hline Chin & Mouth & Lip & Beard & Face & Body \\
\hline Sharp & Tiny & Thin & Thin & Handsome & Tall \\
Flat & Wide & Thick & Thick & Sweet & Short \\
\hline
\end{tabular}

Table 8: Accessories of Cerpen - Gram 4

\begin{tabular}{l|l} 
Styles of Clothing & Menu \\
\hline
\end{tabular}




\begin{tabular}{|l|l|l|l|}
\hline Male & Female & Signature Dish & Beverages \\
\hline Sport & - & Chinese Noodle & Soda \\
\hline Sport & - & lumpia & Tea \\
\hline
\end{tabular}

The examples of task after making cerpen - gram as seen below.

Find the similarities between the differences of the short - story characters.

- The names of the characters in Cerpen - Gram 2 are Kevin and Ekrak.

- Ths students were guided to connect those two characters' names by finding out the similar elements. It could be done by Venn diagram as follows.

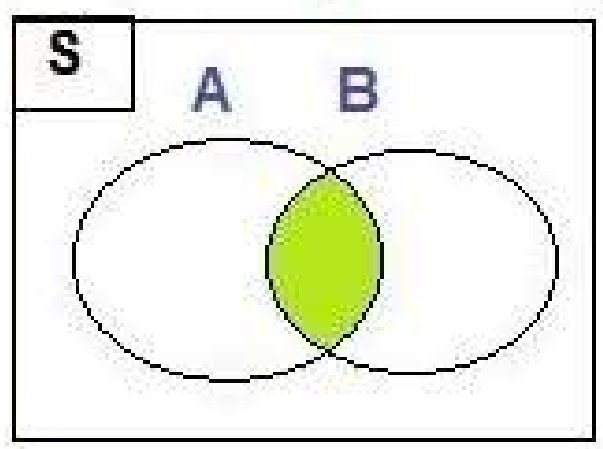

- Given A = Kevin and B = Ekrak.

- Although they are different but they have similariteis.

- From these differences, the students were trained to find the similarities to get the harmony. Then, they were asked to write it as reflection.

- For example:

Kevin is a Chinese breeden born in Banyuwangi. Ekrak is a native of Solo Javanese. They are a badminton male couple. They respect each other. Ekrak, which means as a bin, for Kevin is not a thing to be humiliated. Kevin understands well that the name, Ekrak, was given to him since all of Ekrak's brothers passed away. According an ancient Javancese belief, such kid should not be named as a human to avoid the same thing, same disaster. Thus, the name-Ekrak, does not mean to humiliate him. It has meaning. "Asma Kinarya Japa".

\section{Conclusion}

PPK in empowering multicultural character based culture and exemplary methohds had limited variative and accurate mindset models. There was a need of "role model" by utilizing multicultural of child short story characters which reflectt social-cultural realities. They should be packaged into a literacy pocket book based cerpen - gram (table diagram of intrinsict short - story elements).

It is suggested for further investigations to develop literacy pocket book based on cerpen - gram to empower multicultural characters of primary school students. 


\section{Reference}

[1] Choirul Mahfud: Pendidikan Multikultural. Yogyakarta: Pustaka Pelajar (1997)

[2] Ki Supriyoko, "Pendidikan Masyarakat Multikultural”, Kompas, 26 Januari 2004

[3] Sugiyono: Metode Penelitian Kuantitatif, Kualitatif, dan R \& D. Bandung: Alfabeta (2017)

[4] Faizah, Dewi Utama et al: Panduan Gerakan Literasi di Sekolah Dasar. Jakarta: Dirjen Dikdasmen Kemendikbud (2016)

[5] Tamaya, Elma Excavanti et al: Membaca-Menulis sebagai Metode Belajar Analisis Meta-Teori. JurnalPendidikan. Volume 3 Nomor 3 BulanMaretTahun 2018. 349-356 (2018)

[6] Kanzunnudin, Mohammad: Peran Sastra dalam Pendidikan Karakter. 29 Juni 2012. Jurnal Prosiding Seminar NasionalPendidikan: Pendidikan untuk Kejayaan Bangsa. 195-204 (2012)

[7] Sun, Peng Kheng: Cerpen-Gram. Jakarta: Elek Media Komputindo Kompas Gramedia (2012)

[8] Setyono, Yulian Adi: Pengembangan Media Pembelajaran Fisika berupa Buletin dalam Bentuk Buku Saku untuk Pembelajaran Fisika Kelas VIII Materi Gaya ditinjau dari Minat Baca Siswa. Jurnal Pendidikan Fisika. Vol.1 No.1 Hal. 2338 0691. Surakarta: Universitas Sebelas Maret. (Online) diakses dari https://digilib.uns.ac.id, tanggal 19 Agustus 2019 (2013)

[9] Sukistiono et al: Pengembagngan Bahan Ajar Menulis Cerpen Berbasis Teks dengan Metode Cerpen-Gram. J-Simbol. Volume 5 Nomor 3 Tahun 2017 (2017)

[10] Kokom Komalasari et al: Pendidikan Karakter Konsep dan Aplikasi Living Values Education.

Bandung: Refika aditama (2017)

[11] Muhaimin, A.Ghofirdkk: Strategi Belajar Mengajar (Penerapannya dalam Pembelajaran Pendidikan Agama). Surabaya: CV. Medika Karya Anak Bangsa (1996) 